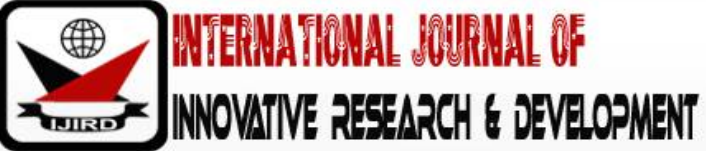

ISSN 2278 - 0211 (Online)

\section{Effect of Business Ethics on Performance of Manufacturing Firms in the South-east, Nigeria: A Study of Coca-Cola Industrial Ltd. Enugu, Nigeria}

\begin{tabular}{|c|}
\hline Nduji Romanus \\
Lecturer, Department of Business Administration, \\
Veritas University, Abuja, Nigeria \\
Oriaku Chris \\
Lecturer, Department of Business Administration \\
Veritas University, Abuja, Nigeria \\
\hline
\end{tabular}

\begin{abstract}
:
Over the years, business failure has become constant news. This may have resulted from boardroom crisis of confidence orchestrated by the neglect of business ethical best practices. The aim of this study is to determine the effect of business ethics on performance of Manufacturing Firms in the south-east, Nigeria with particular emphasis on Coca-Cola Industrial Ltd. Enugu, Nigeria. Regression analysis has been used for this study. The population size is 5493 workers of Coca-Cola Industrial Ltd. Enugu, Nigeria. Out of this the sample size has been fixed at 369. Yamani formula has been adopted. The results obtained shows that organizational equity significantly influences the performance of Coca-Cola Industrial Ltd. Technical integrity has effect on performance of Coca-Cola Industrial Ltd. Enugu, Nigeria ( $r=.775$, $P<.05)$., organizational honesty significantly affects the performance of Coca-Cola Industrial and there is a significant relationship between ethical training and the performance of Coca-Cola Industrial Ltd.It is therefore important that the management of Coca-Cola Industrial Ltd. Enugu, must pay more attention to the issue of business ethics as this will help improve their performance and also restore dying confidence and patronage of their customers.
\end{abstract}

Keywords: Business ethics, technical integrity, honesty, equity, ethical training and Performance, Coca-Cola Industrial Ltd. Enugu, Nigeria

\section{Introduction}

The term ethics is very important in all business organizations be it private or public. Every organization irrespective of size, type of work, place of work, origin needs to follow certain instructions of demeanor. Every company also need to maintain the customers in a gracing manner. Ethics is related to what is good, and what is desired or preferred human conduct' (Etuk, 2019). Every organization should handle ethics as with flippancy (Adeyeye, Adeniji, Osinbanjo and Oludayo, 2015). It is really utmost important for every business to function properly (Adeyeye etal, 2015). According to Ebitu and Beredugo (2015), every organization should be ethically transparent. Any business, to be successful, needs to have a strong foundation of Business/managerial ethics. Business ethics are built upon the many key elements. These are Ethical training, strong code of ethics, ethics coach, trustworthiness, honesty, fairness, technical integrity and confidential reporting system. Ethics are the backbone of any organization. That is why it is important to have a strong code of ethics as well as ethical training in the organization. However. Honesty and Integrity are the fundamental principles influences the business ethics towards the organizational performance cannot be over-emphasized across the globe.

Following the above, this study intends to examine the effect of Business Ethics on Performance of Manufacturing Firms in the south-east, Nigeria (A Study of Coca-Cola Industrial Ltd. Enugu, Nigeria).

\subsection{Statement of the Problem}

The current performance of manufacturing firms in Nigeria have generated plethora of mistrust, doubts, and complains (Amith, 2016). This development has questioned the credibility of made in Nigerian products. Some of these complains centre around their poor compliance with ethics such as honesty, integrity and equity to customers.etc. Also, some of these manufacturing firms are in desperation to maximize their profits at the expense of their customers without adherence to ethical values (Bergman, 2016). The attitudes and conducts of local manufacturers have kept ethics a distance as Quality of Nigerian product has been murdered on the altar of mistrust. Moreover, it is alleged that the poor level of ethical compliance among manufacturing firms have an effect on their performance (Ebitu etal, 2015). Therefore, 
this study examines the effect of Business Ethics on Performance of Manufacturing Firms in the south-east, Nigeria (A Study of Coca-Cola Industrial Ltd. Enugu, Nigeria).

On the whole the study will provide answers to the following pertinent questions;

- What is the effect of organizational equity on performance of Coca-Cola Industrial Ltd. Enugu, Nigeria

- What is the significance of technical integrity on performance of Coca-Cola Industrial Ltd. Enugu?

- To what extent does Organizational honesty affect the performance Coca-Cola Industrial Ltd. Enugu, Nigeria?

- What is the relationship between the ethical training and performance Coca-Cola Industrial Ltd. Enugu, Nigeria?

\subsection{Hypotheses of the Study}

The following hypothetical assumptions have been formulated for validation by this study;

- H01, Organizational equity does not have effect on performance of Coca-Cola Industrial Ltd. Enugu, Nigeria.

- H02. There is no significance effect of technical integrity on performance of Coca-Cola Industrial Ltd. Enugu, Nigeria.H03 Organizational honesty does not affect the performance of Coca-Cola Industrial Ltd. Enugu, Nigeria.

- H04 There is no positive relationship between ethical training and performance of Coca-Cola Industrial Ltd. Enugu, Nigeria.

\section{Ethics}

Rossouw (2019) defined ethics as a set of rules that specifies what is right or wrong. It helps to differentiate between fact and belief. It also helps to apply moral principles based on situation (Hellriegel, Slocum \& Woodman, 2018). Business ethics as a field of study deploys moral analysis and assessments (Rossouw, 2019). The first level is macroeconomic level. Here, business transactions can take place within national or international frameworks (Etuk, 2019).

\subsection{Business Ethics}

In the words of Rossouw (2019), Business ethics refers to contemporary organizational standards, principles, sets of values and norms that govern the actions and behavior of an individual in the business organization. Any business, to be successful, needs to have a strong foundation of managerial and business ethics. Business ethics are built upon the many key elements. These are Ethical training, strong code of ethics, ethics coach, trustworthiness, honesty technical integrity, equity and confidential reporting system (Adeniji, 2015). Business ethics can be defined by two dimensions. The normative level focuses on business behavior and the range and quality of business ethical issues. Business ethics helps to achieve over and above compliance (Ferrell, 2017). Ronald-Duska (2017) argues that unrestrained corporate freedom would benefit company in the long term (Rossouw, 2019). Milton Friedman opined that corporate executives will make as much money as possible while adhering to basic rules of the society (Ebitu, and Beredugo, 2019)

\subsection{Organizational Equity}

Amith (2016) highlighted Organizational Equity as a way to distribute the resources. It first developed by J. Stacy Adams in the year of 1960s for maintain equity between the inputs by workers in workplace (Etuk,2019). According to Equity Theory, it is a tendency to maximize individuals' rewards. Inequalities in relationships will cause unhappiness to a degree proportional to the amount of inequality.

\subsection{Technical Integrity}

Accordingly, to Ferrel (2017), technical integrity is defined as being composed of two separable attributes that reflect the intended, desired emergent properties of a system and the minimization of unintended, undesired emergent properties. An approach for formulating a composite measure of technical integrity is developed from this definition and is presented for critical review. Organizational integrity refers to the ethical integrity of the individual actors, the ethical quality of their interaction as well as that of the dominating norms, activities, decision making procedures and results within a given organization (Ebitu et al, 2015).

\subsection{Ethical Training}

Ethical training refers to the programs which are designed by a firm to promote ethical behavior. An ethics training program provides employees with instructions on how to deal with ethical dilemmas when they occur and improve their overall ethical conduct $(G u y, 2019)$. Unethical business practices and money scandals can result in a huge loss in profit leading to a decrease in employee motivation and ultimately bankruptcy. Fulfilling and maintaining productivity and quality can develop a suitable reputation and keep a healthy code of ethics for the business. For all these reasons ethics training programs are essential for a successful business(Ferrel,2017).

\subsection{Business Ethics and Organizational Performance}

As per Nielson (2019), defined the term business ethics from different point of view. One of this is competitive advantages (Trevino, 2017). Adhering this helps to achieve efficiency in operations, commitment, more engagement and loyalty from the employees (Ferrell 2017). Business ethics could be seen as a constraint on profitability (Vander, Wadlt and Helmbold, 2020). Some studies have maintained that social capital that is part of an organization's marketplace image (Robert and Erika, 2016). 


\subsection{Empirical Studies}

Andow A and Usman F (2016) carried a research on impact of business ethical training and development on performance in flour mills. Kaduna state, Nigeria. The study adopted descriptive survey design with the use a questionnaire to elicit the required information for the study. The hypothesis was tested using t-test analysis as the study population of the study was 615 staff members of the company and sample was drawn using Taro Yamane (1967) formular. The result showed that ethical training and development have impact on performance of flour mill company Plc Kaduna, Nigeria.

Rossouw (2019) carried out a study to determine the effect of ethical equity on performance of service industries in the south east, Nigeria. The population for the study was 157 staff of the selected firm. Questionnaires were used to collect data as the study adopted survey method. At the end of the day the result showed that ethical equity has a significant effect on performance of the service firm in the south east, Nigeria.

Uwa K.L (2018) conducted a study to determine the impact of ethical compliance on organizational profitability in Nigeria. The study adopted descriptive design. 96 subscribers were selected from each of the four telecommunication companies to give the required 384 subscribers needed in the study. The instrument used to collect data was researcher`s developed questionnaires. Regression and correlation tools were used to test the hypothesis. It was revealed the ethical compliance had a positive significant effect on organizational profitability. Hellriegel et al (2018) conducted a survey on the business ethics and performance of service firm in Calabar Cross- River State.

\subsection{Applications of Business Ethics}

On the basis of social and economic elements, the business ethics dimensions vary. In macro ethics, the central question is the fairness of the organizational choice of economic system (Du Plessis, 2010). Researches reveal that in Nigerian society, informal external corporate governance often more influential than the formal external corporate governance (Rossouw, 2009). The internal corporate governance plays an important role (Ogbonna and Ebimobowei,2019). The Balanced Scorecard model reflects the American 'exclusive' shareholder-centered approach to corporate governance (Osisioma,2018).

\subsection{Importance of Ethics in Business}

Ethics in Business pays a significant role. (Uwa, Ubong and Etimfon 2018). Robert, McMurrian and Erika-Matulich (2016) argue that ethics in business plays a vital role in a system of corporation and can lead to businesses making a profit. Osisioma (2018) used a case study of Starbucks to show the importance of ethics. Unethical practices may lead to low employee turnover and high productivity (Trevino,2017). In a trustworthy work environment, employees can reasonably expect to be treated with full respect and consideration by their colleagues (Wolfe,2018).

\subsection{Principles of Business Ethics}

Arising from the above findings of the BE, seven identifiable principles can be identifiedOsisioma,2018).

- Be Trustful: Trust is defined as guaranteed confidence on the attractiveness, capability, forte and truth of a business.

- Integrity: Integrity means completeness of attractiveness by consistency of judgments, words and actions.

- Keep an Open Mind: In order for a company to improve performance, the leader of an organization must be receptive to new ideas.

- Meet obligations: Regardless of the situations a corporation must do everything to gain the belief of past punters' and clients.

- Fairness: Companies tend to be reasonable in their communications with all shareholders.

- Have Clear Documents: Re-evaluate all print resources including small business commercials, flyers, leaflets and other business papers to make sure they are dear detailed and specialized.

- Maintain Accounting Control: Greatest keeping is an imperative module of business ethics.

- Reputation \& Morality: Most Establishments are built around reputation and the morale of the employees.

- Be Respectful: As a good corporate citizen treat clients and customers with utmost respect. Always treat other with professional respect and courtesy.

- Commitment to Excellence \& Leadership: Many businesses today follow fineness in executing their duties

\subsection{Challenges of Business Ethics in Nigeria}

Accordingly, to Etuk (2019), there are some aspects causing challenges to the ethical practices in Nigeria. These are Lack of Professional Managers (lacking competencies), Pre-occupation with profit Maximization (caused due to less amount of financial strength), Lack of confidence \& Sustainability (Not able to maintain confidential information), Reciprocity (involvement in in improper agreements,) commitment from employees etc.

\subsection{Strategies to Promote Business Ethics}

Robert et al (2016) analyses the strategies to promote ethical behaviour to include the following:

- Evaluating Ethical Behaviour: The company should ensure internal ethics audits on a regular basis. The behavioral standards should be communicated among the employees.

- Educating Employees: The company should constantly educate the employees on ethical values. 
- $\quad$ Protecting Employees: Employee must be assured that they will be safe from retaliation from other employees or supervisors who might be turned in for engaging in questionable activities.

- Determine the effect of business ethics on performance of Manufacturing Firms in the south-east, Nigeria with particular emphasis on Coca-ColaIndustrial Ltd. Enugu, Nigeria.

\section{Methodology}

The descriptive survey research design was adopted and the study was guided by four research questions and four hypotheses. The population size of the study was 5493 workers of different departments of Coca-Cola Industrial Ltd. Enugu, Nigeria. Out of which a sample size of 369 was realized using taro Yamani formula of (1964). Questionnaires developed by the researcher were used for data collection. The hypotheses were tested using Pearson product moment correlation coefficient and simple linear regression methods.

\section{Testing the Research Hypotheses}

To test the hypothesis listed above, the work adopted the following statistical tools, Pearson's product moment correlation coefficient and simple linear regression, aided by computer Microsoft special package for social sciences (SPSS)

4.1. Research Hypothesis 1

$\mathrm{H}^{1}$, Organizational equity does not have effect on performance of Coca-Cola Industrial Ltd. Enugu, Nigeria.

\begin{tabular}{|c|c|c|c|c|c|}
\hline Model & R & R Square & $\begin{array}{c}\text { Adjusted R } \\
\text { Square }\end{array}$ & $\begin{array}{c}\text { Std. Error of the } \\
\text { Estimate }\end{array}$ & Durbin-Watson \\
\hline 1 & $.852^{\mathrm{a}}$ & .726 & .725 & .70352 & .064 \\
\hline
\end{tabular}

Table 1: Model Summaryb

a. Predictors: (Constant), Organizational equity

b. Dependent Variable: Organizational performance

\begin{tabular}{|c|c|c|c|c|c|c|}
\hline \multicolumn{2}{|c|}{ Model } & $\begin{array}{c}\text { Sum of } \\
\text { Squares }\end{array}$ & Df & $\begin{array}{c}\text { Mean } \\
\text { Square }\end{array}$ & F ig. & Sig. \\
\hline \multirow{2}{*}{1} & Regression & 426.063 & 1 & 426.063 & 860.842 & $.000^{\mathrm{b}}$ \\
\cline { 2 - 7 } & Residual & 160.855 & 325 & .495 & & \\
\cline { 2 - 7 } & Total & 586.917 & 326 & & \\
\hline
\end{tabular}

a. Dependent Variable: Organizational Performance

b. Predictors: (Constant), Organizational Equity

\begin{tabular}{|c|c|c|c|c|c|c|}
\hline \multicolumn{2}{|c|}{ Model } & \multicolumn{2}{|c|}{$\begin{array}{c}\text { Unstandardized } \\
\text { Coefficients }\end{array}$} & \multirow{2}{*}{$\begin{array}{c}\text { Standardized } \\
\text { Coefficients }\end{array}$} & \multirow{2}{*}{ T } & \\
\cline { 3 - 5 } \multicolumn{2}{|c|}{} & B & Std. Error & Beta & & \\
\hline \multirow{2}{*}{1} & (Constant) & .179 & .090 & & 2.001 & .046 \\
\cline { 2 - 7 } & OE & 1.250 & .043 & .852 & 29.340 & .000 \\
\hline
\end{tabular}

Table 3: Coefficientsa

a. Dependent Variable: Organizational Performance

$$
\begin{array}{lc}
\mathrm{R} & =0.852 \\
\mathrm{R}^{2} & =0.726 \\
\mathrm{~F} & =7.942 \mathrm{E} 3 \\
\mathrm{~T} & =29.340
\end{array}
$$

\subsubsection{Interpretation}

The regression sum of squares indicates that more of the variation in the dependent variable is not explained by the model. The Organizational equity coefficient is 0.852 , indicates that there is positive relationship between Organizational equity and Organizational performance. $\mathrm{R}$ square indicates that $72.6 \%$ of the variation in the Organizational performance is explained by the model. Low amount of standard error has been reported.

The Organizational equity coefficient of 0.852 indicates a positive significance between Organizational equity and Organizational performance, which is statistically significant (with $t=29.340$ ). Therefore, the null hypothesis should be rejected and the alternative hypothesis accordingly accepted.

\subsection{Research Hypothesis 2:} Nigeria.

$\mathrm{H}^{2}$. There is no significance effect of technical integrity on performance of Coca-ColaIndustrial Ltd. Enugu, 


\begin{tabular}{|c|c|c|c|}
\hline & Mean & Std. Deviation & $\mathbf{N}$ \\
\hline Technical integrity & 2.0061 & .85800 & 327 \\
\hline $\begin{array}{c}\text { Organizational } \\
\text { performance }\end{array}$ & 2.5872 & 1.31213 & 327 \\
\hline
\end{tabular}

Table 4: Descriptive Statistics

\begin{tabular}{|c|c|c|c|}
\hline \multicolumn{2}{|c|}{} & $\begin{array}{c}\text { Technical } \\
\text { integrity }\end{array}$ & $\begin{array}{c}\text { Organizational } \\
\text { performance }\end{array}$ \\
\hline \multirow{3}{*}{ Technical integrity } & $\begin{array}{c}\text { Pearson } \\
\text { Correlation }\end{array}$ & 1 & $.776^{* *}$ \\
\cline { 2 - 4 } & Sig. (2-tailed) & & .000 \\
\cline { 2 - 4 } & $\mathrm{N}$ & 327 & 327 \\
\hline Organizational performance & $\begin{array}{c}\text { Pearson } \\
\text { Correlation }\end{array}$ & $.776^{* *}$ & 1 \\
\cline { 2 - 4 } & Sig. (2-tailed) & .000 & 327 \\
\cline { 2 - 4 } & $\mathrm{N}$ & 327 & 327 \\
\hline
\end{tabular}

Table 5: Correlations

**. Correlation is Significant at the 0.01 level (2-tailed)

Table 5 shows the descriptive statistics. There is not much difference in terms of the standard deviation scores. This implies that there is about the same variability of data points between the dependent and independent variables.

Table 5 is the Pearson correlation coefficient for Technical integrity and Organizational performance. The correlation coefficient shows 0.775 . This value indicates that correlation is significant at 0.05 level (2tailed) and implies that there is a significant positive relationship between Technical integrity and Organizational performance $(\mathrm{r}=.775)$. However, since the computed $r=.775$, is greater than the table value of .195 we reject the null hypothesis and conclude that there is a significant relationship between Technical integrity and Organizational performance.

\subsection{Research Hypothesis 3}

H03 Organizational honesty does not affect the performance of Coca-ColaIndustrial Ltd. Enugu, Nigeria.

\begin{tabular}{|c|c|c|c|c|c|}
\hline Model & R & R Square & $\begin{array}{c}\text { Adjusted R } \\
\text { Square }\end{array}$ & $\begin{array}{c}\text { Std. Error of } \\
\text { the Estimate }\end{array}$ & $\begin{array}{c}\text { Durbin- } \\
\text { Watson }\end{array}$ \\
\hline 1 & $.566^{\mathrm{a}}$ & .320 & .318 & 1.07663 & .148 \\
\hline
\end{tabular}

Table 6: Model Summaryb

a. Predictors: (Constant), Organizational honesty

b. Dependent Variable: Organizational performance

\begin{tabular}{|c|c|c|c|c|c|c|}
\hline \multicolumn{2}{|c|}{ Model } & $\begin{array}{c}\text { Sum of } \\
\text { Squares }\end{array}$ & Df & $\begin{array}{c}\text { Mean } \\
\text { Square }\end{array}$ & F ig. & Suly \\
\hline \multirow{2}{*}{1} & Regression & 177.611 & 1 & 177.611 & 153.228 & $.000^{\mathrm{b}}$ \\
\cline { 2 - 7 } & Residual & 376.719 & 325 & 1.159 & & \\
\cline { 2 - 7 } & Total & 554.330 & 326 & & & \\
\hline
\end{tabular}

a. Dependent Variable: Organizational Performance

b. Predictors: (Constant), Organizational Honesty

\begin{tabular}{|c|c|c|c|c|c|c|}
\hline \multicolumn{2}{|c|}{ Model } & \multicolumn{2}{c|}{$\begin{array}{c}\text { Unstandardized } \\
\text { Coefficients }\end{array}$} & $\begin{array}{c}\text { Standardized } \\
\text { Coefficients }\end{array}$ & \multirow{2}{*}{ T } & \multirow{2}{*}{} \\
\cline { 3 - 7 } \multicolumn{2}{|c|}{} & B & Std. Error & Beta & & \\
\hline \multirow{2}{*}{1} & (Constant) & .995 & .148 & & 6.736 & .000 \\
\cline { 2 - 7 } & $\begin{array}{c}\text { Organizationa } \\
\text { l honesty }\end{array}$ & .802 & .065 & .566 & 12.379 & .000 \\
\hline
\end{tabular}

Table 8: Coefficients ${ }^{a}$

a. Dependent Variable: Organizational Performance

$$
\begin{array}{lc}
\mathrm{R} & =0.566 \\
\mathrm{R}^{2} & =0.320 \\
\mathrm{~F} & =7.942 \mathrm{E} 3 \\
\mathrm{~T} & =12.379
\end{array}
$$

\subsubsection{Interpretation}

The lesser value of the regression sum of squares (177.611) compared to the residual sum of squares indicates that more of the variation in the dependent variable is not explained by the model. 
$\mathrm{R}$ square, the coefficient of determination, shows that $32.0 \%$ of the variation in the Organizational performance is explained by the model.

The Organizational honesty coefficient of 0.852 indicates a positive significance between Organizational honesty and Organizational performance, which is statistically significant (with $t=12.379$ ). Therefore, the null hypothesis should be rejected and the alternative hypothesis accordingly accepted.

4.4. Research Hypothesis 4

H04 There is no positive relationship between ethical training and performance of Coca-ColaIndustrial Ltd. Enugu, Nigeria.

\begin{tabular}{|c|c|c|c|}
\hline & Mean & Std. Deviation & N \\
\hline Ethical training & 1.9113 & .91750 & 327 \\
\hline $\begin{array}{c}\text { Organizational } \\
\text { performance }\end{array}$ & 2.6728 & 1.24090 & 327 \\
\hline
\end{tabular}

Table 9: Descriptive Statistics

\begin{tabular}{|c|c|c|c|}
\hline & & $\begin{array}{c}\text { Competing } \\
\text { Strategy }\end{array}$ & Growth \\
\hline \multirow[t]{3}{*}{ Ethical training } & Pearson Correlation & 1 & $.699^{* *}$ \\
\hline & Sig. (2-tailed) & & .000 \\
\hline & $\mathrm{N}$ & 327 & 327 \\
\hline \multirow{3}{*}{$\begin{array}{l}\text { Organizational } \\
\text { performance }\end{array}$} & Pearson Correlation & $.699^{* *}$ & 1 \\
\hline & Sig. (2-tailed) & .000 & \\
\hline & $\mathrm{N}$ & 327 & 327 \\
\hline
\end{tabular}

Table 9 shows the descriptive statistics. There is not much difference in terms of the standard deviation scores. This implies that there is about the same variability of data points between the dependent and independent variables.

Table 10 is the Pearson correlation coefficient for Ethical training and organizational performance. The correlation coefficient shows 0.699 . This value indicates that correlation is significant at 0.05 level (2tailed) and implies that there is a significant positive relationship between Ethical training and organizational performance. It can be concluded that there is a significant relationship between ethical training and organizational performance $(\mathrm{r}=.699, \mathrm{P}<.05)$.

\section{Discussion of Findings}

The findings of this study are discussed under the various objectives of the study.

- Hypothesis one was tested using simple linear regression, to determine the effect of Organizational equity on Organizational performance however the result show that Organizational equity significantly influences the Organizational performance $(\mathrm{r}=0.852 ; \mathrm{F}=7.942 \mathrm{E} 3 ; \mathrm{t}=29.340 ; \mathrm{p}<0.05)$. The utilitarian theory insists that an action is considered to be right or wrong based on the consequences of the action and its effects on the majority of the people (West, 2004). This means that an action or practice is ethically correct when it produces more positive consequences in comparison to negative ones to those who are involved.

- Hypothesis two was tested using the Pearson correlation coefficient, to ascertain the effect of technical integrity on performance of Coca-Cola industry, Enugu, Nigeria. According to the result, the technical integrity has effect on performance of Coca-Cola industry, Enugu, Nigeria ( $r=.775, \mathrm{P}<.05)$.As per Makkreel \& Luft, (2010), this is in line with Kantian deontology theory. This believes that morality must follow some rules (Holzhey \& Mudroch, 2005).

- Hypothesis three was tested using simple linear regression, to examine the influence of organizational honesty on performance of Innson technical manufacturing firm. The result shows that Organizational honesty significantly affects the performance of Coca-Cola industry, Enugu, Nigeria $(r=0.566 ; \mathrm{F}=7.942 \mathrm{E} 3 ; \mathrm{t}=12.379 ; \mathrm{p}<0.05)$. This is in support of Ethical relativism which is a theory that decides whether an action is right or wrong solely based on the moral norms that adhere to the culture of one`s society (Shomali, 2001).

- The result indicates of fourth hypothesis indicates that there is a significant relationship between ethical training and performance of Coca-Cola industry, Enugu, Nigeria( $r=.699, \mathrm{P}<.05)$.

\section{Conclusion}

This research studied the effect of business ethics on performance of Nigerian Indigenous manufacturing firms with particular emphasis on Coca-Cola industry, Enugu, Nigeria. Findings showed that the four ethical variables (equity, technical integrity, honesty and ethical training) all had significant effect on Performance of Coca-Cola industry, Enugu, Nigeria

Hence, this study concludes that business ethics has a significant effect on performance Coca-Cola industry, Enugu, Nigeria. 


\section{Recommendations}

Based on the findings the following are recommended to enhance on Performance of Coca-Cola industry, Enugu, Nigeria.

- Equity or fairness is most important key in any organization; hence the management of Innoson Technical and Industrial Company Ltd Nnewi, Nigeria should ensure that there is no foul play in their operations to rebuild the lost confidence in their customers.

- For high organizational performance, commitment towards adherence to integrity in daily operations is required.

- The management of Coca-Cola industry, Enugu, Nigeria should endeavor to showcase honesty as this will build more trust and cordial relationship with their customers.

- The management of the said firm should promote ethical activities by engaging workers on training that will force ethical activities into their doings.

\section{References}

i. Adeyeye, J.O, Adeniji, A. A., Osinbanjo, A.O., Oludayo, O.A (2015). Effects of Workplace Ethics on Employees and Organizational Productivity in Nigeria. International Conference on African Development Issues (CU-ICADI), 267-273.

ii. Amith.M (2016) Business Ethics and Its Importance in Banking Industry. International Journal of Scientific Research and Modern Education(IJSRME) ISSN (online): 2455- 5630) vol1, Issue 11,2016

iii. Andow H.A and Usman F.I (2017).Impact of Business Ethics on Organizational Performance in Flourv Mills, Kaduna State, Nigeria. Sahel Analyst: Journal of Management Sciences Vol. 15.No 1.2017,University of Maiduguri

iv. Bergman, M., (2016) 'The Relationship between Affective and Normative Commitment: Review and Research Agenda,' Journal of Organizational Behavior, 27(5), 645-663.

v. .Ebitu, E.T. and Beredugo, S.B. (2019). Business ethics and the performance of service firms in Calabar, Cross river state, Nigeria. European Journal of Hospitality and Tourism Research, 3(2):28-38.

vi. Ebitu E.T. (2015). Promoting ethical behaviour in business in Nigeria and International market, International Journal of Innovation In Management Sciences, 4(2), 126-130

vii. Ferrell, O. C. (2017). Business Ethics and Customer Satisfaction, Academic of Management Executive, 18(2): 126-129.

viii. Guy, M. E. (2019). Ethical Decision Making in Everyday Work Situations. New York: Quorum Books.

ix. Hellriegel et al (2018) Business ethics and performance of service firm in Calabar Cross- River State. Journal of Business Management, Unical, Vol 5(3)

x. Nielson, R. P. (2018). 'Changing Unethical Organizational Behaviour: Academy of Management Executive' 3 (2) 123- 130.

xi. Trevino, L. K. (2017). Ethical Decision making in Organization: A Person - Situation Interactionist Model. Academy of Management Review 11(3) pp. 601-617.

xii. Vander Wadlt, G. and Helmbold, R. (2020). The Constitution and a New Public Administration. Cape Town: Jut and Co. Ltd.

xiii. Wolfe, R. T. (2018). Impact of Accountability and Ethics on Public Service Delivery: A South African Perspective. South Africa: Nelson Mandela Metropolitan University, Por Elizabeth. Ogbonna, G.N and Ebimobowei, A. (2019). Ethical Compliance by the Accountant on the Quality of Financial Reporting and Performance of Quoted Companies in Nigeria. Asian Journal of Business Management, 3(3): 152-160, 201.

xiv. Osisioma, B. C. (2018). Ethics and Professionalism: The Challenge for the Certified National Accountant. ANAN Mandatory Continuous Professional Development (MCPD)

a. Lectures, May 23, Enugu, Nigeria.

xv. Robert, C. McMurrian and Erika Matulich (2016). Building Customers Value and Profitability with Business Ethics. Journal of Business and Economics Research, 4(November) Pages 13-15.

xvi. Rossouw (2019) Effect of ethical equity on performance of service industries in the south east, Nigeria.UNN Journal of Management Sciences, Vol 6(3)

xvii. Uwa K.L, Ubong, A, Etimfon, E. j (2018). Ethical compliance and Organizational Profitability of Telecommunication Companies in Nigeria European Journal of Business and Innnovation Research, vol 6, No 2,Pp 8-17 